\title{
Anne Sexton, Singer: 'Her Kind' and the Musical Impetus in Lyric Confessional Verse
}

Tyne Daile Sumner

If you can find it,

the music takes place in a grotto,

a great hole in the earth.

(Anne Sexton, 'The Nude Swim', Live or Die 35)

The impetus for creation usually came when Anne directly invoked the muse at her desk. Here, she read favourite poems of other poets - most frequently Neruda - and played certain evocative records over and over... Music acted in some way to free her to create, and she often turned the volume up loud enough to drown out all other sounds. (Kumin xxvi)

$\mathrm{I}$ her 1970 essay 'Rock Poetry, Relevance, and Revelation', Helen English comments on what she calls the 'painted pony' of the 'educational merry-go-round'. 'Too much and too often,' she writes, 'we teachers of English approach poetry through analysis. This method might be fine for the college prep student, who is more capable, but this analysis is where the average student gets turned off. Not all students are capable of handling the analytical approach, but almost all of them "feel" a piece of literature in some way' (1123). Certainly, more often than not, we 'feel' a piece of poetry somehow, even though we might try to mask those feelings with an analytical sophistication; an attempt to approach poetry through an intellectual rather than sensory methodology. Whether read or spoken, to the scholar, the poet, the musician or the classroom teacher, many contend that poetry's primary objective is to communicate experience. Moreover, as English suggests, poetry almost always has a profoundly influential acoustic effect upon us. She writes: if poetry communicates the poet's feeling or emotive experience, it has a liberating effect on the reader or listener. It releases the inner sea of feeling. Music does the same thing' (1123). 
A heightened attention to 'feeling' over scholarly analysis was perhaps in the mind of Steve Rizzo, a budding guitarist and student of American confessional poet Anne Sexton, when he decided to put her poem 'Ringing the Bells' to music at Wayland High School in Wayland, Massachusetts in the 1960s. Having read Edward Arlington Robinson's 'Richard Cory' under Sexton's tutelage, and later having listened to the musical adaptation of the poem by Simon and Garfunkel, Rizzo likely began to perceive not only the musical capacities inherent in lyric poetry, but also the serendipity of his situation as the musically proficient student of one of America's most promising new poet sensations. In her biography on Sexton, Diane Middlebrook details how Rizzo borrowed the poet's collection To Bedlam and Part Way Back after class before inviting Sexton and her fellow teacher Robert Clawson to hear his guitar settings of 'Music Swims Back to Me', ('Music pours over the sense / and in a funny way / music sees more than I. / I mean it remembers better'), 'Johnny Pole', and 'Ringing the Bells' (Middlebrook 286-87).

It is both ironic and conspicuously apt that 'Ringing the Bells' was one of the first of Sexton's poems to be set to a melody. From her breakthrough collection, the poem - despite the enterprise suggested by its title - exudes a kind of juvenile reluctance towards the idea of trained musical engagement. It begins:

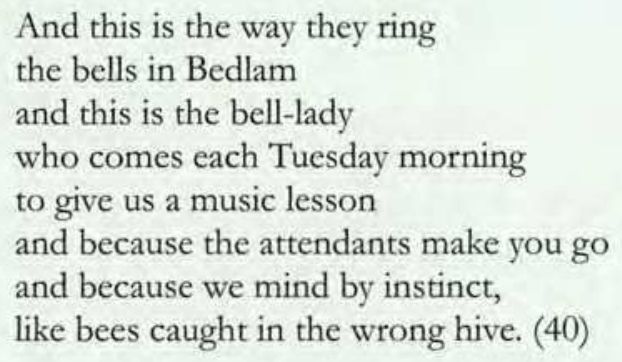

The protagonist of the poem is told to play her ' $\mathrm{E}$ flat', not for enjoyment, but seemingly for something productive to do. She is subordinate to her instructor, appearing institutionalised: 'made to go'. There is a sense of 'eat, sleep, play music' - the choppy stanza suggests an almost farcical progression through a series of organised mechanical movements. Several critics, most notably Ralph J. Mills and Diana Hume George, have commented on the picture of institutional therapy generated by the poem. George notes the poem's "cruel parody of the "trembling bells" of childhood ... wherein the "bell-lady" comes each Tuesday morning to the asylum to conduct the patients in musical therapy' (28). Such a reading draws parallels between music's explicit organising principles and the regimented daily obligations of an institutionalised patient. Mills is similarly attentive to the poem's 'frighteningly realistic picture of therapy at a hospital', yet also highlights the 'marvelous artistic proficiency combined with an uncompromising vision 
of human actuality' that he claims can be expected of Sexton (111). Of Sexton's capacity to infuse lyric verse with melodic intonation, Mills writes: 'The mixture of simplicity and sophistication in rhythm and diction, building up through one long sentence, terrible in understatement, and concluding in another, three-word sentence that compresses all the agony and helplessness and resignation of her dilemma, exhibits this poet's brilliant technical mastery' (111). However real (or perceived) the containment expressed in this poem is, the idea of vocalising it to musical accompaniment sparked Sexton's interest and she began the practice of reading her poetry to any tune that was available. Middlebrook details the collaboration that soon developed, noting, 'Clawson invited a friend who was a professional pianist, Bill Davies, to listen to Sexton read while Steve strummed the songs. Davies liked it, and agreed to help work out the musical ideas' (287). It was out of this unique conception that Sexton's band was formed: Anne Sexton and Her Kind. With the poet using her voice like an instrument, accompanied by a combination of drums, electric piano, guitar, flute, and bass, the group was soon after booked for their debut at a Boston nightclub.

This article considers Anne Sexton's short-lived, mesmerising ensemble as a model for the wider musical impetus in lyric confessional verse. It argues that Sexton used the inherent audibility of the lyric poem - in live readings, recorded readings, and music contexts - to create the illusion of an authentic authorial event. Using lyric poetry theory as a foundation, I assess Anne Sexton and Her Kind (hereafter 'Her Kind') alongside its mid-twentiethcentury literary and publicity contexts, as a means of exploring the reception and efficacy of the touring collective. A key consideration of the article is the array of illusionary tactics available to Sexton's band that allowed her to challenge the formalist approach that had dominated the poetry readings of many of her predecessors. Finally, given that almost no comprehensive criticism exists on the topic of Sexton's brief musical collective, the article analyses Her Kind to begin considering some of the ways in which the mode of mid-twentieth-century confessional poetry overlaps with musical composition.

Her Kind delivered its first performance in July 1968 at a benefit in Boston for American politician-poet Eugene McCarthy, who at the time was the first candidate to challenge Lyndon Johnson for nomination for the US presidency. Writing to biographer and psychotherapist Lois Ames about the performance, Sexton was characteristically frank:

Anne Sexton and Her Kind performed ... at Eugene's 2 in Kenmore Square. A benefit for McCarthy and no dough, but a trial run anyhoo. No one could hear us, people drank and talked, the cash register bonged, the glasses clinked, but a few people (the important ones) liked it a lot. Maxine said we'd make a fortune - though she's so aghast at my performing self - she says 
it's Elizabeth. Did I ever tell you about Elizabeth? She's manic-Anne and sometimes sexy-Anne ... At any rate we got a PAID (\$1000.00) performance for Sept. $20^{\text {th }}$ at DeCordova Museum in Lincoln. A very swinging place. It was where I first heard Merwin (my first reading ever). (Anne Sexton: A Self Portrait in Letters 326)

The Boston Sunday Globe was similarly candid, declaring: 'Her Kind aims to enhance poetic message with music; its members are concerned with getting things down for audiences, not theses' (27). With Sexton in a long satin dress and the band's members in coats and ties, Her Kind thrilled worshipful audiences with recitations of Sexton's poems; the band's flautist Gerald Oshita remarked of the unfolding phenomenon, "we really had a product ... now it was time to see whether it would take off as a business' (Middlebrook 330).

Certainly, if there was ever a good time for a poet to address the audiences of popular music it was the 1960 s in the United States. It was a scene in which, as LeRoy Ashby remarks in his comprehensive history of American popular culture since 1830, With Amusement for All, 'American entertainments spun with dizzying speed' and 'popular culture burst with renewed creativity' (348). In many ways music reflected and influenced what Ashby calls the era's 'social ferment', a period marked by unprecedented growth, agitation, political turmoil, and widespread cultural excitement (372). As Bob Clawson, the manager of Sexton's band, soon discovered, it was also a good time to turn the conflation of poetry and music into a business venture. Simon and Garfunkel, one of the many groups achieving popularity through imaginative work with poetic language, already exerted a heavy influence over Her Kind's guitarist, Steve Rizzo. The Beatles, the Doors, and Bob Dylan were also writing highly lyrical songs, providing audiences with exciting poetic musical experiences. At precisely the same time as these and several other bands constituted the vanguard of popular rock music, poet and translator Burton Raffel wrote of the relationship between music and written text:

Both music and poetry are, in a sense, languages within languages. Organized sound - perhaps the broadest definition of music - is scarcely ever a communications system in the way that words are: music speaks, to be sure, but if its message is to be translated into verbal terms only the most elementary expressions are recognizable. But in the manipulation of its proper component parts - pitch, rhythm, instrumental color, dynamics, and the like - music is closely analogous to speech. To capable musicians, indeed, the expressions of musical communication are apt to be as meaningful as strictly verbal statements. (453)

It is perhaps theories like Raffel's that contributed to Her Kind's strangely marginalised status: while the band received positive media attention, never did they seem to fall into the category of being a music group in their own right. Sexton was a poet, first and foremost, and therefore could hardly 
begin to shake the label of 'poet-performer' in order to be seen simply as a member of her namesake band, whether it was her private objective or not. Thus, unlike the elaborate counterculture philosophy of the Doors, or the unprecedented electronic recording effects used in The Beatles' psychedelic rock, Her Kind had relatively modest goals. Middlebrook notes how the band's musicians set out to write 'backup rhythms and song motifs to alreadyexisting poems', in most instances to pieces whose 'images and associational structures lent themselves to rock arrangements. Sexton learned to deliver words in an acoustical envelope formed by the instruments' (303). One of the band's later members even wrote of the technical application of poetry to a musical score: 'We were not trying to set Anne Sexton's poetry to music, we were trying to embellish it... Music is so mathematical; fitting the poem into music, you make it keep musical time. We were trying to produce an acoustic package in which hearing her read was the artistic goal' (Middlebrook 330).

Alternating between four and five members as the group evolved artistically, Her Kind started rehearsing seriously in the spring of 1968, and by the summer they had constructed the better part of a seventeensong repertoire. Fittingly, the group debuted in a voluntary performance to McCarthy, the only published poet in the US Senate. Thus, although the band's first public recital was marketed as the performance of a band, Sexton could have expected the attendees to have read, and therefore recognise, her poetry. As Middlebrook notes: 'Sexton hoped that performances by Her Kind would expand her audiences' (305). The poet's primary intention, then, seemed to be more related to the reinvention or perhaps 'repackaging' of her poetry than the creation of an entirely new artistic form. As she told an interviewer in the summer of 1968: We call our music "Chamber Rock" ... it opens up my poems in a new way, by involving them in the sound of rock music, letting my words open up to sound that can actually be heard, giving a new dimension. And it's quite exciting for me to hear them that way' (Kevles 108).

Sexton's daughter, Linda Gray Sexton, provides an account that touches explicitly on the poet's insight into the state of musical popular culture at the time. Gray Sexton recalls: 'Her Kind, a group of musicians with an electric keyboard, an acoustic guitar, a flute, saxophone, bass, and drums, created original music to enhance Mother's poetry as she read it aloud. It was almost a rock group, more than a poetry reading' (154). As Sexton herself also pointed out, the 'poets' most listened to in America in the 1960s were in fact those who combined their poetry with music to create a lyric. She noted: People flock to Bob Dylan, Janis Joplin, the Beatles - these are the popular poets of the English-speaking world' (Kevles 109). Naturally, she wanted to maintain artistic control of the group. However, in order to attract the desired new audiences, publicity for Her Kind stirred the waters of an increasing antiintellectualism reverberating throughout the counterculture (Middlebrook 
305). Sexton let the musicians take the lead and they made some surprising choices. 'Woman with Girdle', a poem about the grotesquery of old age, was set to a slow, languid boogaloo melody, which Middlebrook noted, 'enhanced the poem's strengths, revealing the immanence of a goddess archetype in the imagery' (305). The poem reads:

slow motion like a rolling pin,

over crisp hairs, that amazing field

that hides your genius from your patron;

over thighs, thick as young pigs,

over knees like saucers,

over calves, polished as leather

down toward the feet. (All My Pretty Ones 40)

The poem presents a somewhat vulgar blazon, drawing on Petrarchan conventions of representing the female object as only discrete parts of the whole ('Your midriff sags toward your knees'; 'You pause for a moment, / tying your ankles into knots'). Yet with the accompaniment of wind instruments and soul-influence, the lyric becomes facetious and deeply eccentric. The almost grisly tone of the written text changes to triumphant; one can perhaps picture the old, plump subject of the poem rolling her garment, 'down that pink snapper and hoarder'.

The effect of other combinations was just as surprising. The poem 'Cripples and Other Stories' was accompanied by a strange country-pop hybrid sound: opening with a sardonic appeal to the speaker's doctor, the poem, which has been described by one critic as 'a kind of pyrrhic gratification' (Boyers 67), begins:

My doctor, the comedian

I called you every time

and made you laugh yourself

when I wrote this silly rhyme.

Each time I give lectures

or gather in the grants

you send me off to boarding school

in training pants.

God damn it, father-doctor,

I'm really thirty-six.

I see dead rats in the toilet.

I'm one of the lunatics. (Live or Die 80)

The poem mockingly corroborates the often-criticised view of confessional poetics as mere pathological fixation. We witness the relationship between doctor and patient, confessor and penitent. However, Sexton presents an amused (or amusing) version, wherein a doubling of doctor/comedian distorts the traditional format: the desire to please and the withholding of 
pleasure. The speaker in the poem is unquestionably infantilised - rendered, as is typical of the confessing subject, powerless and abject. Yet the rhyme structure of the poem belies its seriousness. The 'ballad-like nursery rhymelike technique', as Sexton described it, helps to 'underscore the horror of the action' (Gill, 'Anne Sexton and Confessional Poetry' 439). As Jo Gill has pointed out, 'the mundane and the extraordinary are thrown into startling and memorable relief, thus drawing attention to one of the ways in which confessionalism achieves its effects' ('Anne Sexton and Confessional Poetry' 439). Subsequent rhymes of 'shame' with 'nickname', 'this' and 'orifice', 'fever' and 'leave her', complete the confession. Perhaps it is fitting then that a poem as sardonic as 'Cripples and Other Stories' was set to a generally temperate musical form, the harmonies of which were accompanied by mostly string instruments such as acoustic guitars, banjos and fiddle, as well as harmonicas. The poem's derisive tone would likely have been amplified by a jarring contrast with the maudlin sound offered by country music. It is conceivable that listeners would have been confused at first, then bemused, and perhaps a bit affronted. But as the countless available anecdotes about Sexton's obsession with her public and critical reception suggest, any response for the poet was better than no response at all.

So what exactly is it about the kind of poetry Sexton was writing that afforded such a smooth - and profitable - genre adaption? Is the act of setting poetry to music more about the choice of poetry or is it about the musical decisions that have to be enacted alongside the written text? Sexton's confessional poetry belonged to the lyric practice, a poetic form in which, as Peter Middleton has summarised in 'The Contemporary Poetry Reading', 'the listener is made aware of the illocutionary force of the utterances in ways that cannot always be signaled by written linguistic markers' (268). Thus, while speaking the words aloud, the reader of poetry instigates a transient act of ownership; for the duration of the reading, the words 'become words to which the reader lends a life' (Middleton 268). Middleton's support for this stance connects the 'ordinary act of speaking in conversation' with the 'individuality of the speaker', the first being an index for the latter. The physical presence of the speaker, therefore, acts as their 'warrant' for their ownership of and relevance to 'a specific body, point of view, and history' (268). All of these things are, of course, amplified when the speaker of the poem is the author, in which instance the poetry reading acts doubly, as presentation of the poem and an overt presentation of authorship; or, for Middleton, 'the reader of poetry performs authorship' (268).

Indeed the principal divide between prose and poetry is not only the look of the words on the page but also the sound of the language. In addition to this, the concept of poetic authenticity - still alive in studies of confessional poetry and, arguably, at the heart of Her Kind's popularity - 
demands interrogation alongside an analysis of a band responsible for such a remarkable development in genre-mixing. After the advent of the confessional school of poetry in the 1950 s, and throughout the second half of the twentieth century, the period in which art-school graduate Hedwig Gorski coined the term 'performance poet', ideas about poetry and authenticity have adapted and evolved, yet precise classifications remain as elusive as ever. ${ }^{1}$ Today, the term 'lyric poetry' brings with it an established body of sound technologies, performance practices, and a poetics geared specifically towards interrogating the boundaries, and indeed the possibility, of sincerity. A description by Peter Middleton illuminates the most commonly held understanding of what poetic authenticity might look and sound like today. He writes: 'A person stands alone in front of an audience, holding a text and speaking in an odd voice, too regular to be conversation, too intimate and too lacking in orotundity to be a speech or a lecture, too rough and personal to be theater' ('The Contemporary Poetry Reading' 262). What renders this account valuable is not necessarily its anecdotal function in describing contemporary poetic performance practices, but rather its navigation of the many assumptions that underpin discourses surrounding the concepts of lyric poetry, intimacy, sincerity, persona, privacy, and confession. All strongly linked and yet highly contested sites, these ideas return again and again to the question of authenticity. Is there a way to quantitatively measure poetic authenticity? Do some poetic practices lend themselves more towards the revelation of truth than others? Even if a poet is telling the truth, how can we ever know for certain? Because this movement towards objective, precise measurement is both ill-advised and ultimately impossible, the question must be relinquished in favour of a more productive method of poetic analysis. To turn more specifically to Sexton's confessional poetry, then, the ideas of sincerity and intimacy have become tethered to the relentless pursuit of biographical fact. However, rather than attempting to quantify the biographical accuracy of confessional verse, an assessment of the dynamic and influential nature of the lyric form provides - at least as a starting point - a theoretical position from which to consider the musical politics and performance of a heretofore somewhat unanalysed poet-turned-rockstar.

Today, of course, the term 'lyric' has come to be associated with the words of a song. This connection with musicality is the vestige of an ancient time: the word derives from the Greek lyrikos ('singing to the lyre'), where a lyre would be played to the accompaniment of sung verse. Throughout her teaching career, Sexton frequently noted the musical capacities of poetry, emphasising its role in the transmission of narrative through successive generations. In her role as the Crashaw Chair in Literature at Colgate University,

1 In the early 1980 s, Gorski began broadcasting live poetry by radio from Austin, Texas, with the accompaniment of a jazz band called East of Eden. For an account, see Wheeler 172. 
NY, in the spring semester of 1972 , she opened one of her lectures with the following remarks of the relationship between lyric poetry and song:

Lyric poetry was originally intended to be sung. The Greek lyrics that have come down to us are probably among the earliest of this form. Lyric poems were more commonly songs in praise of something ... a song in praise of a good harvest, a song in praise of love or laments, grief over the death of a loved one, grief over the loss of someone or some thing. The lyric more or less enshrines a moment, a situation, a single part of time. ('Lecture Five', Crashaw Lectures at Colgate University)

Furthermore, as a former student and friend of Robert Lowell's and mentored by such writers as John Holmes and W.D. Snodgrass, Sexton would likely have known and understood the musical lineages of lyric poetry and therefore comprehended the capacity inherent in her verse for heightened lyrical engagement. Of Lowell's influential teachings throughout his writing seminar at Boston University in September 1958, Sexton remarked, 'He taught me great. It was as easy as filling an empty vase. After all, I didn't know a damn thing about any poetry really' (Middlebrook 93-94). Also important to the development of these kinds of ideas was Sexton's enrolment in 1957 in a poetry workshop that was held evenings at the Boston Center for Adult Education by poet and then Tufts University Professor John Holmes. Diane Middlebrook notes that 'what Sexton learned when she began studying poetry ... were the tricks [Sexton's word] of making smooth, complex stanzas. Her early poems were ... short, often humorous self-deprecating, and frequently sentimental; rhythm and rhyme are vehicles for the delivery of messages' (51). In a poem entitled 'A Little Uncomplicated Hymn' from her 1966 collection Live or Die, for example, she presents strong insight into the musicality of her confessional verse. The poem begins:

I wanted to write such a poem

with such musics, such guitars going;

I tired at the teeth of sound

to draw up such legions of noise;

I tired at the breakwater

to catch the star off each ship;

and at the closing of hands

I looked for their houses

and silences. (69)

The poem stresses a fear the poet has that she is being dishonest, that she does not, as Robert Boyers writes, 'deserve to sing songs of pure peace and harmony' (70). In addition to an affective reflection on the act of lyrical production, however, the poem seems to suggest that for the poet, writing music is, practically speaking, impossible. With its long consideration and exemplification of a failure to write the hymn intended - 'a little uncomplicated 
hymn / is what I wanted to write' - the poem invokes a famous notion from T.S. Eliot's 'The Love Song of J. Alfred Prufrock': 'It is impossible to say just what I mean!' Jo Gill notes this connection between Sexton and Eliot in her excellent assessment of the ways in which Sexton's defence of the 'personal' and the private invokes and challenges Eliot's influential dictum wherein he advocates the 'process of depersonalization' and the separation between 'the man who suffers and the mind which creates' ('My Sweeney, Mr Eliot' 40). Thus, what can be seen to exist in both lyric theory and Sexton's own musings is the idea that, although it carries a traditional relation to melody, the lyric - an arrangement that has no sound - is not music. Susan Stewart posits the perceived audibility of the lyric as such: ' $[\mathrm{U}]$ nless we are listening to a spontaneous composition of lyric, we are always recalling sound with only some regard to an originating auditory experience' (29). Stewart goes on to state that 'the sound recalled in lyric is not abstract, not a succession of tones without prior referents; rather the sound recalled is the sound of human speech' (see Hollander). Consequently, and because we can never fully reconstruct the auditory conditions of a poem's germination, our recalling of it, whether we intend it or not, will always incorporate some element of imagination. It is the lyric's inextricable remnants of song, along with the form's inclination towards performance, which necessitate, in almost all accounts of lyric poetry, an insistence on the presence of a listening, observing 'other'. Or, to quote John Stallworthy, who complicates this idea even further, 'A poem is a composition written for performance by the human voice' (2028). Lesley Wheeler has later added to this, dividing voice's connotations into two useful categories: textual voices, which refers to voice as a metaphor employed by poets and critics in and about works in print, and voiced texts, which include poems recited, read aloud, performed by authors, actors, students, and others (18). As Stallworthy and Wheeler's remarks suggest, the lyric is always a written form, however, its fruition arrives only with its oral declaration.

Despite its obscure lineage, the lyric can be defined by a number of consistent characteristics: it is typified by brevity, promotes the essence of a performance, utilises a first-person speaker or persona, and provides an outlet for personal emotion. Acceptance of these four qualities is common to most lyric theory; however, the lyric has also undergone dramatic transformation. Various definitions of lyric mirror the many stages of its evolution. According to Deborah Nelson, its principal transformation came in the 'epistemological and ontological shift that occurred after the revolutions in France and the United States at the end of the eighteenth century' (xvi). The product of this revolution still predominates today, consisting almost exclusively of an emphasis on the 'meditative' form of lyric, which has 'increasingly [come] to stand in for the lyric as a whole' (Nelson xvi). This kind of meditation or introspection in poetry is of course bound up with the cultivation of 
individualism, a trademark of the Romantic poets and arguably the inception of many of the stereotypes of poetry and poets that exist today: the poet as an aggrieved and melancholy visionary. The solitary, meditative figure evoked by the English Romantic poet Percy Bysshe Shelley's depiction of the 'passerine' poet in his essay 'A Defence of Poetry' demonstrates this unreserved investment in meditation:

A poet is a nightingale, who sits in darkness and sings to cheer its own solitude with sweet sounds; his auditors are as men entranced by the melody of an unseen musician, who feel that they are moved and softened, yet know not whence or why. (512)

Although the passage sustains Nelson's notion of the lyric poet's introspection, Shelley's anthropomorphised nightingale nevertheless reveals one of lyric poetry's most vexing definitional problems. The description of a speaker (the self-cheering poet) who is paradoxically both unaccompanied and perceived by an entranced group of 'auditors', poses an inescapable question: is the compositional activity of lyric poetry inherently private, or is it public? Certainly, the idea of an 'unseen musician' is not without its exponents. In 'What is Poetry?' nineteenth-century philosopher John Stuart Mill presents poetry as an introspective utterance that is not defined by audience. Notably ardent in his observations about the ultimate privacy of lyric poetic expression, Mill defines the nature of this utterance by means of a distinction between poetry and eloquence:

Poetry and eloquence are both alike the expression or uttering forth of feeling. But ... we should say that eloquence is heard, poetry is overbeard. Eloquence supposes an audience; the peculiarity of poetry appears to us to lie in the poet's utter unconsciousness of a listener. Poetry is feeling confessing itself to itself, in moments of solitude ... Poetry, accordingly, is the natural fruit of solitude and meditation; eloquence, of intercourse with the world. (12-13) ${ }^{2}$

Contemporary theorist Northrop Frye went on to modulate Mill's terms, demarcating what could perhaps be appropriately called the necessity of overhearing'. Reinforcing the influence of Mill's description, Frye states that 'the basis of generic distinctions in literature appears to be the radical of presentation' and that the lyric is 'pre-eminently the utterance that is overheard' (249). Frye further claims that the 'lyric poet normally pretends to be talking to himself or to someone else' (249).

In The Idea of Lyric W.R. Johnson, who gives three categories for examining lyric pronouns, further complicates discussion of the presence of an overhearing 'other'. Emphasising what he calls the 'wonderful impossibility'

2 For significant responses to Mill's 'overheard utterance', see W.R. Johnson; Cameron; and Culler, The Pursuit of Signs. For a historical perspective, see Waters, 1-17. For important commentaries of the role of 'address' in lyric, see Burr; Keniston 9. 
of unanimously defining the lyric, Johnson states a series of designations: the 'I-You' poem, in which the poet addresses or pretends to address his thoughts and feelings to another person; a second category comprising T.S. Eliot's meditative poem, in which the poet addresses himself or no one in particular; and finally, 'the poem cast as dialogue, dramatic monologue, or straight narrative', whereby the poet is absent entirely, presenting instead a voice or series of voices without directly interfering in the presentation. ${ }^{3}$ Other critics have rejected the relevance of the poet altogether, rendering the intersubjectivity of the poem entirely dependent on a reader's individual engagement with the text. Herbert Tucker provides a possible explanation for this, arguing that the oral convention in poetry is so powerful that we infer a speaking voice even though we are consciously interpreting words on the page. The 'inference' espoused by Tucker is elaborated by Jonathan Culler who states that 'when we overhear an utterance that engages our attention, what we characteristically do is to imagine or reconstruct a context: identifying a tone of voice, we infer the posture, situation, intention, concerns and attitudes of a speaker' ('The Modern Lyric' 295).

As I have stated in introducing these ideas, studies of lyric poetry's inherent audibility indicate again and again the need to privilege voice and sound as key elements of a genre whose traditional definition was cemented in music. As Robert Von Hallberg has noted,

lyric authority is inextricable from its sister act, music: Euterpe, the muse of lyric poetry, needs a flute; Terpsichore, the muse of choral poetry, a lyre. Diverse forms of musicality are attractive to poets, but no poet can afford to tap only lightly the musical resources of language. (7)

However, while these vacillations point to the important literary and social shifts through which the lyric has journeyed, almost all modern accounts of lyric speech are profoundly influenced by Mill's conception of the 'overheard' utterance. Consequently, the lyric has come to be associated with un-mediation or un-interruption, concepts with which the lyric performers of Ancient Greece were likely unfamiliar.

Charting this evolution from the lyric's mediated, adjudicated classical antiquity through to the heightened intimacy associated with both confessional and lyric poetry initiates a number of questions concerning not only the motive/s of the poetic speaker, but also the relative preconceptions of the listening subject. For instance: does the poet intend to be overheard or is she ambivalent about the presence of the inquisitive auditor? To return to Mill's conceptualisation of poetry, then, and the notion that 'the peculiarity of poetry appears to us to lie in the poet's utter unconsciousness of a listener',

3 Johnson reads Tertullian's meditation on the peacock as a reminder of the 'problem of lyric or the problem of genre in general'. See W.R. Johnson, The Idea of Lyric 2. 
the kind of reception that Her Kind received could not be more incongruous. As Eugene Pool recalled in a Boston Globe review of one of the band's shows:

The performance was informal and warm and there was no real interruption out of respect. For Anne Sexton and Her Kind do deep and moving work about insanity, lost love, death, and life that is emotionally cataclysmic strung out against Her Kind's eerie, insinuating music. (202)

Thus, through the use of music and popular culture, Sexton attempted what could aptly be called a revolution: a reconceptualisation of herself as a poet as well as the contemporary concepts of art and identity. Fusing private writing, celebrity, and music, the band entered shrewdly into the relationship between what came to be called 'confessional poetry' and the new celebrity culture after the popularisation of television.

So what makes a live musical performance of Sexton's poems more accessible and entertaining than perhaps, for instance, T.S. Eliot's 'The Wasteland' put to guitar or Paradise Lost accompanied by harp? First, there is the issue of voice: confessional poetry's restoration of the first person ' $\mathrm{T}$ ' to the centre of the poem is perhaps the most influential factor in the process of reception. The placement of the speaking ' $\mathrm{I}$ ' at the core of the lyric means that, first, the poet's private self becomes both the speaker and the subject. Second, that the poem begins to address the reader directly, and thirdly, the persona developed by the poem becomes involved in an act of intimacy, as if the reader is known to the speaking 'I'. The 'I', as Lesley Wheeler has recently pointed out, acts as 'a metaphor for originality, personality, and the illusion of authorial presence within printed poetry' (3). So when the 'I' from the printed page takes to the stage, the intense intimacy of a confessional performance is heightened. In addition to this phenomenon, for Sexton and her band, the marriage of poetry and music on the stage coincided serendipitously with a boom in America's sound innovations. Thus, voice's 'fascinating excess of connotations' not only marked significant challenges to how lyric poetry has been defined, but also accounts for the new complications of voice for "twentieth and twenty-first century poets and their audiences because of changing sound technologies and their profound influence on U.S. culture' (Wheeler 2).

The 1920 s and 1930 s in America saw poetry's aural reception undergo dramatic transformation as the nation experienced unprecedented developments in acoustical technologies, including the booming popularity of radio. The popularisation of radio significantly influenced the soundscape of American culture, acting in part as a precursor to the notion of poetry reading as we now understand it. This transformation hinged largely on radio's modification of the relationship between the notions of personal and impersonal - or rather, I would suggest, modifications to what readers and listeners of poetry held to be the meaning of 'presence'. The artistic and 
technological development of a new 'poetics of presence' coincided with the transpositional nature of the confessional poet's 'live confession', working, as Paula Salvio suggests, 'to enlist the sororial and fraternal sympathies of the listener so as to exonerate the sinner and, in turn, efface the differences between them' (30). Anne Sexton often appealed to the intimacy inherent in the live-reading process, openly admitting to a self-reflexive failure to leave sin alone' (Kevles 105) in her use of the stage to seek 'an appeal before a trial of angels' (Salvio 30). An increased emphasis on the presence of the poet, as opposed to demonstrations of vocal dexterity or mastery of content, not only acted to subvert the high modernist insistence on impersonality, it worked to create the illusion of an authentic authorial event. ${ }^{4}$ So, the poet subsumed the poetry, as the emphasis on personality became a subconscious attempt to combat the grasp that new technologies such as radio and television had attained over American culture. This phenomenon - that is, the substitution of a literal, historical self for a literary self as the voice of the poem - necessitates, in the case of the confessional poets, an appreciation that voiced texts are as significant as textual voices.

However, unlike the printed poem, which in most instances brings with it the implicit veneration ascribed to published books, the live poetry reading or poetry-to-music performance does not always present the most convenient object of study. Such is the nature of live reading that its atmosphere becomes equally influential - if not more influential - than the content of the poetry being enunciated. Factors such as the clothing worn by the event's speakers, the length and dimensions of the room in which the reading is held, and an endless series of other significant yet paradoxically incalculable factors become a guiding factor in audiences' responses to a reading or musical performance. Although the live reading can be recorded, either aurally and/ or visually, it is an ephemeral event. It stands to reason, then, that when a poem exists as a heard performance, its meaning differs from that of the traditional printed form.

For Charles Bernstein, this process has powerful consequences insofar as 'rather than looking at the poem - at the words on a page - we may enter into it, perhaps get lost, perhaps to lose ourselves, our (non-metrical) "footing" with one another' (11). Sexton expertly perceived this latent acoustical potential in her own work, adopting in her 1966 collection Live or Die a loose versification geared specifically towards the artistic goal of performance poetry. In poems such as 'Flee on Your Donkey', 'Consorting with Angels', and 'Wanting to Die', she appears to have partly relinquished any prior allegiance to formalism,

4 See Christopher Grobe's 'The Breath of the Poem: Confessional Print/Performance circa 1959' (PMLA 127.2 [2012]: 215-30) for a relevant elaboration on the conjoined history of poetry and performance art with a focus on the work of Anne Sexton and Robert Lowell. 
focusing instead on poetry's richness as a spoken art. The result of Sexton's 'behind the scenes' work saw the compositional act of writing poetry become a stage-oriented pursuit, in which the lyric poem could be conceived of chiefly as monologue. Bernstein has scripted the influential quality of the vocalised poem literally, stating:

PERforMANCE readily allows FOR stressing ('promoting') unstressed syllaBLEs, Including prepOsitions, artiCLES, aNd conjunctionIONS creating SynCoPAtEd rHyThms, which, onCE hEArd are Then carried oVer by readERS iNTo their oWN reading of tHe text. (15)

Somewhat paradoxically, then, the poetry reading or performance acts as a spectacle in which the poet's spoken voice competes with the written poetic voice that he or she has previously constructed; that is, "the "acting" takes precedence over letting the words speak for themselves or worse, eloquence compromises, not to say eclipses, the ragged music of the poem' (Bernstein 11). And, of course, when music is added to this construct, genre demarcation becomes even fuzzier. However, as Pool astutely noted of a performance by Her Kind:

Although it may seem surprising that a poet should get together with a group of musicians, it really shouldn't, since it's been happening ever since the Beats in the fifties went into coffeehouses to read jazz. They built up quite an audience for poetry, and then Bob Dylan stole it by reversing the procedure and mixing music with poetry, and ever since the poets have been trying to get it back. (202)

While Anne Sexton and Her Kind attracted the attention of newspapers, critics, and fans alike, the group's touring career spanned only approximately three years. Middlebrook summarises the factor that likely contributed most to the termination of the band: 'Under Bob Clawson's active management, the group eventually went upstate New York, to Michigan, and as far west as Fargo, North Dakota. But even though Sexton was always happy to rehearse, she was never happy to get on a plane, and so Her Kind was grounded too. When the group disbanded in 1971, she was relieved as much as disappointed' (330). Indeed, although an ephemeral thing, Her Kind radically pushed the boundaries of confessional verse and reignited the long-standing debate over the latent musicality in lyric poetry. To conclude, here are the reflections of one reviewer, clearly moved by the nonchalant, trailblazing ensemble: 'You should watch for Anne Sexton and Her Kind and go to see them. The Jordan Hall audience loved them, and so will you for what they can tell you about yourself and your happy, hurting life'. Her Kind 'put poems to rock, blues, and jazz in such a very moving way that, if you weren't there, you should have been' (Pool 202). 
'Anne Sexton and Her Kind.' Boston Sunday Globe, 20 April 1969: 27. Web. 20 March 2013.

Ashby, LeRoy. With Amusement for All: A History of American Popular Culture since 1830. Lexington: UP of Kentucky, 2006. Print.

Bernstein, Charles. Introduction. Close Listening: Poetry and the Performed Word. Ed. Charles Bernstein. New York: Oxford UP, 1998. 3-25. Print.

Boyers, Robert. 'Live or Die: The Achievement of Anne Sexton.' Salmagundi 2.1 (5) (1967): 61-71. Web. 20 March 2013.

Burr, Zofia. Of Women, Poetry, and Power: Strategies of Address in Dickinson, Miles, Brooks, Lorde, and Angelou. Urbana: U of Illinois P, 2002. Print.

Cameron, Sharon. Lyric Time: Dickinson and the Limits of Genre. Baltimore: Johns Hopkins UP, 1979. Print.

Culler, Jonathan. The Pursuit of Signs: Semiotics, Literature, Deconstruction. Ithaca: Cornell UP, 1981. Print.

—. 'The Modern Lyric: Generic Continuity and Critical Practice.' The Comparative Perspective on Literature: Approaches to Theory and Practice. Ed. Clayton Koelb and Susan Noakes. New York: Cornell UP, 1988. 284-300. Print.

English, Helen W. 'Rock Poetry, Relevance, and Revelation.' English Journal 59.8 (1970): 1122-27. Web. 1 Nov. 2014.

Frye, Northrop. Anatomy of Criticism. Princeton: Princeton UP, 1957. Print.

George, Diana Hume. Oedipus Anne: The Poetry of Anne Sexton. Urbana: U of Illinois P, 1987. Print.

Gill, Jo. 'Anne Sexton and Confessional Poetry.' Review of English Studies, New Series 55.220 (2004): 425-45. Web. 20 March 2013.

"My Sweeney, Mr. Eliot": Anne Sexton and the "Impersonal Theory of Poetry." Journal of Modern Literature 27.1-2 (2003): 36-56. Web. 20 March 2013.

Hollander, John. 'The Music of Poetry.' Journal of Aesthetics and Art Criticism 15.2 (1956): 232-44. Web. 20 March 2013.

Johnson, W.R. The Idea of Lyric: Lyric Modes in Ancient Modern Poetry. Berkley: U of California P, 1982. Print.

Keniston, Ann. Overbeard Voices: Address and Subjectivity in Postmodern American Poetry. New York: Routledge, 2006. Print.

Kevles, Barbara. 'The Art of Poetry XV: Anne Sexton.' No Evil Star: Selected Essays, Interviews and Prose. Ed. Steven E. Colburn. Ann Arbor: U of Michigan P, 1985. 83-111. Print.

Kumin, Maxine. 'How It Was: Maxine Kumin on Anne Sexton.' The Complete Poems: Anne Sexton. Boston: Houghton Mifflin, 1981. Print.

Middlebrook, Diane Wood. Anne Sexton: A Biograpby. New York: Vintage, 1992. Print.

Middleton, Peter. 'The Contemporary Poetry Reading.' Close Listening: Poetry and the Performed Word. Ed. Charles Bernstein. New York: Oxford UP, 1998. 262-99. Print.

Mill, John Stuart. 'What is Poetry?' Essays on Poetry by Jobn Stuart Mill. Ed. Parvin Sharpless. Colombia: U of South Caroline P, 1976, Print. 
Mills, Ralph J. 'Anne Sexton.' Anne Sexton: Telling the Tale. Ed. Steven E. Colburn. Ann Arbor: U of Michigan P, 1988. 110-24. Print.

Nelson, Deborah. Pursuing Privacy in Cold War America. New York: Columbia UP, 2002. Print.

Pool, Eugene. 'Anne Sexton, Her Kind Mix Poetry with Music.' Anne Sexton: Telling the Tale. Ed. Steven E. Colburn. Ann Arbor: U of Michigan P, 1988. 202-203. Print.

Raffel, Burton. 'Music, Poetry, and Translation.' Antioch Review 24.4 (1964-1965): 453-61. Web. 1 May 2014.

Salvio, Paula M. Anne Sexton: Teacher of Weird Abundance. New York: State U of New York P, 2007. Print

Sexton, Anne. Live or Die. London: Oxford UP, 1967. Print.

—. To Bedlam and Part Way Back. Boston: Houghton Mifflin, 1960. Print.

- Anne Sexton: A Self-Portrait in Letters. Ed. Linda Gray Sexton and Lois Ames. Boston: Houghton Mifflin, 2004. Print.

—. All My Pretty Ones. Boston: Houghton Mifflin, 1962. Print.

_. 'Lecture Five.' Crashaw Lectures at Colgate University, 1972. Austin: Harry Ransom Humanities Research Center at The University of Texas.

Sexton, Linda Gray. Searcbing for Mercy Street: My Journey Back to My Mother, Anne Sexton. Berkeley: Counterpoint, 1994. Print.

Shelley, Percy Bysshe. Poetry and Prose. Ed. Donald H. Reiman and Neil Fraistat. New York: Norton, 2002. Print.

Stallworthy, Jon. 'Versification.' The Norton Anthology of Poetry. $3^{\text {rd }}$ ed. Ed. Alexander W. Allison et al. New York: Norton, 1983. Print.

Tucker, Herbert F., Jr. Browning's Beginnings. Minneapolis: U of Minnesota P, 1980. Print. Stewart, Susan. Poetry and the Fate of the Senses. Chicago: U of Chicago P, 2002. Print. Von Hallberg, Robert. Lyric Powers. Chicago: U of Chicago P, 2008. Print.

Waters, William. Poetry's Touch: On Lyric Address. Ithaca: Cornell UP, 2003. Print.

Wheeler, Lesley. Voicing American Poetry: Sound and Performance from the 1920s to the Present. Ithaca: Cornell UP, 2008. Print. 
Copyright of Australian Literary Studies is the property of Australian Literary Studies and its content may not be copied or emailed to multiple sites or posted to a listserv without the copyright holder's express written permission. However, users may print, download, or email articles for individual use. 


\section{University Library}

\section{- M M N E R VA A gateway to Melbourne's research publications}

Minerva Access is the Institutional Repository of The University of Melbourne

Author/s:

Sumner, TD

Title:

Anne Sexton, Singer: 'Her Kind' and the Musical Impetus in Lyric Confessional Verse

Date:

2014-05-01

Citation:

Sumner, T. D. (2014). Anne Sexton, Singer: 'Her Kind' and the Musical Impetus in Lyric Confessional Verse. AUSTRALIAN LITERARY STUDIES, 29 (1-2), pp.90-106. https:// doi.org/10.20314/als.56d23ba6f6.

Persistent Link:

http://hdl.handle.net/11343/285309 